\title{
Transatlantica
}

Revue d'études américaines. American Studies Journal

Line Breaks in America: the Odds and Ends of Poetry

\section{"You are next in line": Moving down the Line(s) with Ron Padgett}

\section{Olivier Brossard}

\section{(2) OpenEdition}

1 Journals

\section{Electronic version}

URL: https://journals.openedition.org/transatlantica/17248

DOI: $10.4000 /$ transatlantica. 17248

ISSN: $1765-2766$

\section{Publisher}

Association française d'Etudes Américaines (AFEA)

\section{Electronic reference}

Olivier Brossard, "'You are next in line": Moving down the Line(s) with Ron Padgett", Transatlantica [Online], 1 | 2021, Online since 01 July 2021, connection on 03 February 2023. URL: http:// journals.openedition.org/transatlantica/17248 ; DOI: https://doi.org/10.4000/transatlantica.17248

This text was automatically generated on 3 February 2023.

\section{(c) (i) (9)}

Creative Commons - Attribution-NonCommercial-NoDerivatives 4.0 International - CC BY-NC-ND 4.0 https://creativecommons.org/licenses/by-nc-nd/4.0/ 


\title{
"You are next in line": Moving down the Line(s) with Ron Padgett
}

\author{
Olivier Brossard
}

\section{Introduction}

1 In 1992, the Poetry Society of America and the Metropolitan Transportation Authority launched the literary program "Poetry in Motion" which consists of poetic campaigns in the subway and other public spaces. In his film Paterson (2016), Jim Jarmusch takes the idea of poetic motion literally as the hero Paterson, a New Jersey bus driver, writes his lines of verse in his spare moments behind the wheel during his daily driving routine. The poems were not written by Jarmusch-although he studied poetry and writing with Kenneth Koch at Columbia University-but by Ron Padgett, sometimes affiliated to the so-called second generation of New York School poets, and one of the inspirations for the film. In his poem "I'll Get Back to You" (How Long, 2011), Ron Padgett hints at the daydreaming quality and meditative instability of his poems, one thought sweeping away another. As he is attempting to write a poem in which he would entertain several thoughts at once-hence the disjunctive presence of brackets-he finally manages to "get back" to the earlier train of thought he wanted to jump on:

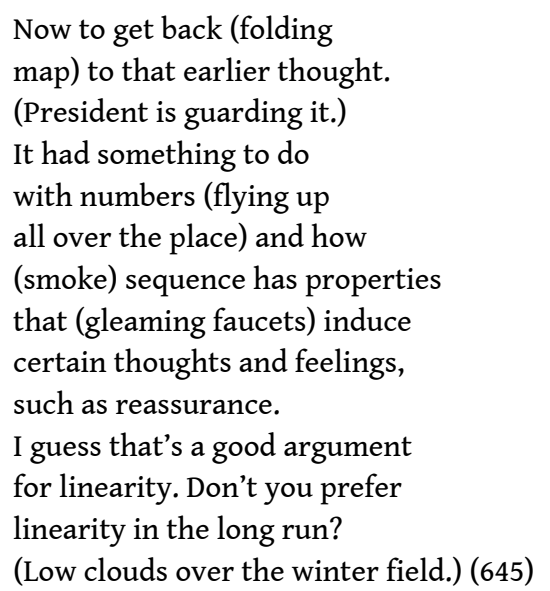


2 That a self-interrupting poet trying to hold several thoughts at once should be advocating linearity might seem ironic. However, I would argue that he is not interested in the drab wintery linearity of the final bracketed line. Rather, Padgett seems to prefer "linearity in the long run," an expression hinging on his poetics of form and of line breaks. To be linear is to have the characteristics of "a line and especially a straight line," as well as to be "based [on] sequential development" (Merriam Webster). Linearity has to do with formal disposition as well as linguistic content. Since Padgett imagines it "in the long run," we might as well forget about logical sequential development for now: so much for "reassurance." However, linearity, a semblance of coherent narrative, might be construed over several lines, with the risk of being indefinitely deferred: "I'll get back to you" is an invitation to follow the poet and poem, with no guarantee that whoever-maybe not even ourselves-will get back to us. For Ron Padgett, who has been practicing disjunctive poetics for more than fifty years, "linearity in the long run" might be a definition of verse, all the more so as the expression suggests the possibility of the run-on line. A poem is a series of lines that run into-or just follow-each other and simply pile up; a poem is a long run on lines.

3 There is no word in French for "line break": "retour chariot" and "saut de ligne" refer to hitting Enter on a keyboard, but they are by no means related to poetry per se. Whether in French or in English, enjamb(e)ment is related to the line break without being synonymous with it. In his thorough study "Exploring the Conceptual Implications of Poetic Line-break: from Terminology to Phenomenology," Frank Kjørup unravels the word cloud which has formed around line breaks: enjambment, run-on lines, line-ends, line-endings, end-stopped (lines), lines as structural elements, lines as word sequences. Those words are so often loosely used as synonyms for line breaks that the concept runs the risk of being hollowed out of its meaning (21). The line break is a paradoxical notion, at once very specific and general, a precise set of poetic coordinates and a generic aspect of poetry: writing on line breaks is like writing on every single line of poetry ever written. Another paradox: although line breaks are everywhere in poetry and critical discourse, according to Kjørup no one really seems to be able to say exactly what they are.

Line-break, hardly at the top of anyone's list of the lexically arcane, nonetheless seems to have escaped the attention, or failed to catch the interest, of established lexicography: OED has no record of the word, neither in the latest printed edition nor online. No less surprisingly: nor in the modern standard reference books within the specialised field of poetics or related fields (stylistics, metrics) are there to be found any separate entries on line-break; in neither dictionaries nor encyclopaedias; neither the New Princeton Encyclopaedia of Poetry and Poetics (1993) nor the Old (1965, rev. ed. 1974), nor any of the other established classics in the field.

Apparently, we have before us a case of terminology most mysterious: a modern poetic term the phenomenal referent of which, judging from the popularity of its use, would seem to be central, while in contemporary official records of terminology it is marginalised to the point of seeming non-existent. (Kjørup 21)

Even if Padgett says he's no "theoretician of language," he wonders "why [it is] that [he] seems to write so often about writing." Throughout his career as a poet, Padgett has explored the possibilities of line breaks, trying to define such paradoxical space time (dis)continua. About his desire to explore the mystery of language, Padgett says that maybe it can't be put into words because "words can't be used to describe themselves" (“Ape Man" 484): since line breaks, understood as the space between lines, 
do not have words "in" them, then maybe words can be put to use to describe or circumvent them. And I would argue line breaks in Ron Padgett's poetry are the sites and pretexts for his metatextual poetics.

There is something wonderfully honest about the word "line-break" as it displays its own duality: it's a line and it's a break, and when present, the hyphen itself hesitates between representing the former or the latter. Temporally, the word indicates that the break takes place at the end of the line, not at its beginning-although what comes before is also crucial. There is something terminal about the name "line break"; on the contrary, "enjambment" or "run-on line" posit the following line as their destination. And yet, line breaks depend on the existence of a subsequent line, or else it's the end of the poem, what Agamben calls its "falling into silence" when the final rhyme has the last word:

[...] I would like to examine a passage in De vulgari eloquentia in which Dante seems, at least implicitly, to pose the problem of the end of poetry. The passage is to be found in Book II, where the poet treats the organization of rhymes in the canzone (XIII, 7-8). After defining the unrelated rhyme (which someone suggests should be called clavis), the text states: "The endings of the last verses are most beautiful if they fall into silence together with the rhymes" (Pulcherrime tamen se habent ultimorum carminum desinentiae, si cum rithmo in silentium cadunt). What is this falling into silence of the poem? What is beauty that falls? And what is left of the poem after its ruin? (Agamben 114)

There is a difference however between "the falling into silence of the poem" and the "beauty that falls," if we consider the latter as the downward movement of the poem itself. The line break only allows a temporary silence of the poem, followed by a fall from one line to the next: the "ruin" of the poem is delayed as long as line breaks offer the hope of a sequel to the line. The ambiguity of the concept of line break lies in its hesitation between process or action (line-breaking: the two lines produced by the process of line-breaking become part of its definition) and result, a point in space and time ("break" as noun). Denise Levertov underlines the tension between point and process in her 1979 essay "On the Function of the Line" where she defines the line break as a form of exploratory punctuation opening up the poem to new interpretive possibilities, based on a momentary hesitation and rejection of semantic closure:

In what way is contemporary, non-metrical poetry exploratory? What I mean by that word is that such poetry, more than most poetry of the past, incorporates and reveals the process of thinking/feeling, feeling/thinking, rather than focusing more exclusively on its results [...]. And the crucial precision tool for creating this exploratory mode is the line-break. The most obvious function of the line-break is rhythmic: it can record the slight (but meaningful) hesitations between word and word that are characteristic of the mind's dance among perceptions but which are not noted by grammatical punctuation. [...] In poems one has the opportunity not only, as in expressive prose, to depart from the syntactic norm, but to make manifest, by an intrinsic structural means, the interplay or counterpoint of process and completion-in other words, to present the dynamics of perception along with its arrival at full expression. The line-break is a form of punctuation additional to the punctuation that forms part of the logic of completed thoughts. Line-breakstogether with intelligent use of indentation and other devices of scoring-represent a peculiarly poetic, a-logical, parallel (not competitive) punctuation. (Levertov 30-31)

7 It is not certain, however, that the line break is just another "device of scoring," that it is simply "additional," "not competitive." Nor should it be considered solely for its 
"effect on the melos of the poem" (267). What line breaks generate "on top of" and against traditional punctuation is the vertical (and visual) dimension of the poem. Levertov's metaphors of parallelism and counterpoint seem to eschew the tense articulation of the lines of verse on and around the space of the line break-as opposed to the simultaneous punctus contra punctum unfolding of melodic lines in counterpoint, which theoretician Frank Kjørup insists is constitutive of line-breaks:

With respect to line-break, now, to my intuition, there is a sense in which that term would be employed less aptly to the metrical (auditory) aspect of verse than to the graphical (visual) aspect, the latter being that to which the very concept of line may be said to stand in a relation most literal, line as referring to writing being employed in a sense everything but loose. Here, there is a sense in which the more neutral line-boundary (or, slightly more linguistically-technical, line-juncture), much

rather than line-break, would appear the more inclusive term as well. (Kjørup 24)

What is a line break then? Is it a space, an action, a turn, a movement, a direction, a disposition, a disposal, a before and after, a transition, a translation, an expectation, a promise, a pause, a leap, a fake end, a temporary ending, a rehearsal for an end to come? Is it spatial, temporal, both?

Yasmine Shamma devotes a chapter of her book Spatial Poetics to "Ron Padgett's InnerOuter Spaces," grounding her reading of Padgett's work in Michel de Certeau's distinction between space and place in The Practice of Everyday Life:

"A place is thus an instantaneous configuration of positions. It implies an indication of stability. A space exists when one takes into consideration vectors of direction, velocities, and time variables. [...] On this view, in relation to place, space is like the word when it is spoken, that is, when it is caught in the ambiguity of an actualization...." (The Practice of Everyday Life, 117)

The outset of this chapter marks the point at which the spatial agenda merits articulation: Padgett's poetry celebrates space and reject place. Specifically, Padgett's most recent collection, How Long, pronounces confluences of time and space alongside a favoring of "movements," "time variables," and "intersections" of vectors," over "distinct location," and "stability"-or, more simply, space over place. (Shamma 152)

In Shamma's "close-readings that illuminate the ways in which Padgett creates a New York City poetry [...] ultimately rejecting the limits of its place," (152) the unidentified spaces of line breaks are mostly left unexplored. ${ }^{1}$ I would like to follow in Yasmine Shamma's footsteps and agree with her that Padgett's "poems actively reject limits of 'place' instead celebrating (and sometimes mourning) what can be lost and found within created or practiced space." (155) I would add that such a rejection is also happening and enacted in and around line breaks, which, borrowing the term from de Certeau, we might call "non lieux" (or "nowhere in places" in the English translation), when place is changed "into passages." ${ }^{2}$ Yasmine Shamma quotes Michel de Certeau's comparison of the passers-by's "turns" and "detours" to the "turns of phrase" or "stylistic figures," insisting on the "rhetoric of walking." (Certeau, in Shamma 162) The space opened by the line breaks are turns and detours one has to go through in order to move forward/downward in the poem. The question, then, is: what is happening linguistically or conceptually in such pivotal spaces where language is cut short only to resume on the next line? If line breaks are the "non-lieux du poème," how is passage enacted through and with them?

11 In my reading of Padgett's poems, I would like to keep in mind the following remarks: first, line breaks are decisions in the etymological sense of the word (from the Latin 
de - off and caedere - cut). I will try to explore the poetic logic of such decisions. Second, what "line break" does not have in its name is what it creates: verticality. Or gravity, if one thinks of William Blake's "Introduction" to Songs of Innocence, where the poetshepherd gives up instrumental music to start singing, which he subsequently gives up to write. The moment when he starts writing "in a book that all may read" is precisely when the line break is materialized on the page by a long dash. It is also the moment when the poet is told to sit down by the child/angel he sees on a cloud. Broken lines sit on top of one another. In this world of gravity, verse allows not only phonic rhymes (also possible in prose) but visual rhymes along a vertical axis. In Blake's poem, "read" and "reed" show that the poem is not only meant to be heard but also to be seen, once written with a rural pen: although phonetically identical, "reed" placed below "read" reveals its one-letter difference. Reading poetry is reading the line breaks: reading not only from left to right, but also from top to bottom to top again. Line breaks articulate the $\mathrm{x}$ and $\mathrm{y}$ axis of the poem.

Fig. 1

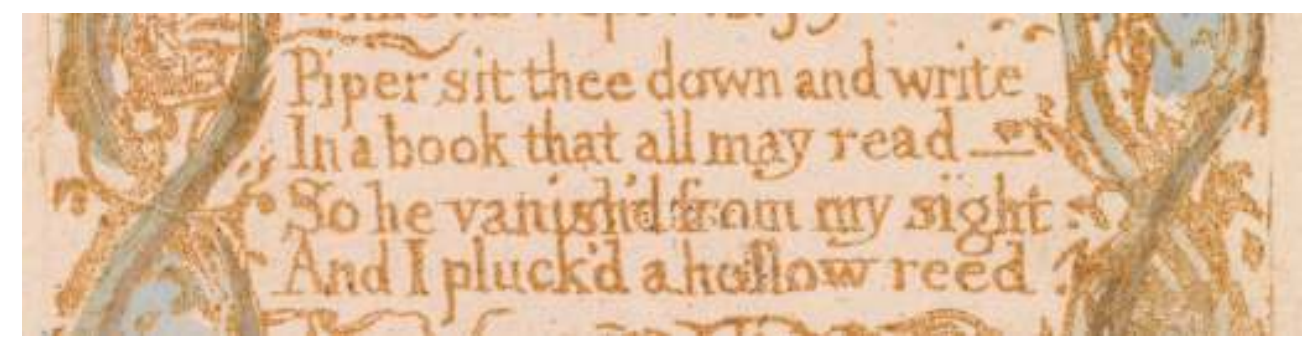

Detail from William Blake's Introduction to Songs of Innocence (1789)

It is tempting to ask oneself if line breaks correspond to a set of recurrent characteristics in Ron Padgett's poetry. Can one do a survey of what line breaks are, do, and mean in the poems? Such an enterprise would no doubt elicit more than a smile from the poet. ${ }^{3}$ And yet, I believe it is useful to try and map his line breaks to see where one stands (or how one falls down the lines).

During the Poets and Critics Symposium devoted to his work in Paris in 2017, Ron Padgett answered a question about the disruption of syntax in his poetry, addressing his use of line breaks:

There's a poem in here [the volume Collected Poems] that begins by saying, "A moment ago, my heart thump went." "That's not correct English, you know. You would say "a moment ago my heart went thump." But by disrupting the rhythm of the line, it echoes the disruption of the cardiac movement, [...] so that it serves a purpose. [...] The same thing could be said for line breaks as well. [...] Line breaks [...] are maybe the most important thing about a poem, except the prose poem. [...] I happen to think line breaks are really important for the flow of the syntax to either make the poem flow fast, or to make it stop, or to stop and go. You really can control the flow of the syntax by the line-breaks [...] Sometimes if I've written a poem that doesn't feel right, I will break the lines differently just to see, because it gives you a fresh feeling for what that poem is or might be, another look, you know.

One would be hard pressed to find a theory of line breaks in Padgett's works or essays. However, as he explained during the Paris symposium, making or unmaking a poem depends on the fashioning of the lines and, ultimately, on the line breaking process. Ron Padgett has an experimental practice of line breaks, "just to see" how the poem reacts to new line configurations: this practice engages both the auditory quality of the 
poem (the flow and rhythm of the syntax) and what Alice Notley calls its "visionary"5 dimension. In her essay on Padgett's work, Alice Notley is primarily writing about the nature of images in her friend's poetry: even when she mentions "the leaps between 'frames' [which are] breathtakingly steep" in the early poems, she does not so much address such leaps in relation to vision. What happens from one frame to the next, when frames correspond to lines? Run-on-lines are paradoxical spaces: mostly invisible (or simply ignored), they decide the course and the look of the poem under a new line configuration.

Ron Padgett's practice of line breaks in order to obtain a "fresh feeling for what the poem is or might be" follows a long tradition of poetic experiments. During the symposium, Padgett mentioned his readings of the imagists and William Carlos Williams: ${ }^{6}$ Williams's quest for a new foot in American poetry as well as his experiments with lines were certainly an influence. We may want to read Padgett's versifying practice as deriving from Williams's "line breaks [...] best explained as speech-based, utilizing syntax, intonation, and pace" (Holsapple 137), as Padgett's playful rewriting of "This is Just to Say" shows. ${ }^{7}$ Closer to Padgett, one should also mention O'Hara's strolling along Manhattan streets, down the jolty lines of his poems, his line breaks revealing "the / profile of a city / exploding against the old dull bed." (O'Hara, "Seven Nine Seven" 433). Or "the suspended life" created by line breaks in John Ashbery's seminal The Tennis Court Oath (1962) where the lyric subject is repeatedly suspended and undermined by what Denise Levertov calls "the line-break's fractional pause" (268). Ron Padgett also explores such pauses, "the slight (but meaningful) hesitations between word and word" (Levertov 266) in relation to breath: in "Don't Forget" (1976), Padgett writes

Great perceptions of the oceans and the plains,

contemplation of the biggest mountains in their ranges,

philosophies of snow at their tops and theologies of the clouds

that hang forever from their ears and send mist

into the atmosphere I breathe in

and out, a delicate moisture

that keeps my body supple so the mind can operate

in its various ways [...] (169)

The line break separating inhaling from exhaling may be reminiscent of Robert Creeley's articulation of breath, syntax, and line breaks in his poems, for instance in "Le Fou" which stages "a passage in and out of containment, along broken lines of breath" (McHugh 14). However relevant such connections may be, they are rarely obvious or stated as such in Padgett's poems, simply because "early influences, whether artistic or any kind, become so transformed throughout one's life that it's not that they're not there anymore, it's just that they take subtle and different shapes, blended to such a degree with the other things you are that it's very different to sort them out" (Lenhart 106).

What Ron Padgett shares with Williams, with O'Hara, Ashbery, Creeley, and more generally with poets associated with or influenced by Allen's seminal anthology The New American Poetry (1960) is a belief in the open, inquiring nature of line breaks, as poet and critic Heather McHugh writes in her brilliant essay "Love and Frangibility: An Appreciation of Robert Creeley": "The line-breaks place in the inquirer's way precisely the kinds of tour and detour that keep an inquiry moving." (10) Line breaks and enjambments create spaces of inquiry into the nature of language, when readers, 
reaching the end of the line, might hesitate between the "referential power of words" and their "self-referential" dimension (Halter 105). Line breaks are agents of change in language and experience, as Heather McHugh writes about Creeley's "The Window":

Looked at closely, this poem is an etude in that precise and psycho-prosodical art which keeps a line-break subtle. I say psychoprosodical because a line can seem calculated to lead a reader toward presumptions which, in the wake of the line break, he will have to relinquish. A poem changes a reader's mind. And one of the ways it does so is through this play of sentence (the unit of thought in English syntax) against line (the unit of poetic disposition). Sometimes predisposed, sometimes postdisposed, the trail of anticipations and reconsiderations is, in fact, the meaning of passage: for passage is something we have to navigate, through all its straits and turns. (McHugh11)

The "play of sentence [...] against line" (or vice versa) is also what is going on in Ron Padgett's poetry: I would suggest his line breaks are defined by versatility: they are versatile moments, spaces, and agents. To be versatile means to "turn with ease from one thing to another": this is one definition of line breaking, turning from one line to the next to compose verse. Versatile also means "to change or fluctuate readily": I argue that line breaks are variables in Padgett's poetic equations. Lastly, the adjective also means to be "capable of turning forward or backward [...] of moving laterally and up and down" (Merriam Webster): the conceptual movements implied by Padgett's line breaks are indeed versatile, allowing the reader to go backward and forward, to move up and down and sideways.

I will first concentrate on Ron Padgett's bris de vers and show how line breaks point to moments of crisis (distance, absence) in the poem. I will then question the movements that line breaks displace, and more particularly the descent of the poem into itself, as if the poem repeatedly said "drop me a line" to its genitor. Lastly, I will read Ron Padgett's poetry as a matter of line and death.

\section{Bris de vers: Interruptions}

\section{Line Wiggles}

Flipping through the thick Collected Poems, one is impressed by the variety of poetic shapes and forms: long short-line poems, short long-line poems, long long-line poems, short short-line poems, poems with words scattered on the page, prose poems. All kinds of line breaks can be seen and experienced in such diverse landscape, to the extent that Ron Padgett stretches the definition of line breaks, as the following examples will show. 


\section{Jet Plane}

\section{Flies across sky}

21 In the one-line poem "Jet Plane," there seems to be no line breaks; yet, since the title is also the first line of the poem, as well as the subject of the verb of the first-also second -line, can we not consider that we have a line break of a new kind? Poetic space exploration is on the poet's agenda:

(Toujours l'amour, 1976 185)

gray line wiggle

a large permanent flinch

just under the skin then

She turned to me

in the $\quad$ in the

tiny (there are no straight lines in a curve) breeze

breeze curving

In the experimental "Big Blue Jay Composition," is the dotted curve in the middle of the line a new embedded form of enjambment? Technically no, since it is at the very heart of the line, but it materializes the jumps the reader makes from lines to lines. In the 
long prose poem "Arrive by Pullman," Ron Padgett even manages to apply line breaks qua page-breaks to prose poetry, which was thought impossible.

(Triangles in the Afternoon, 1979 317)

Arrive by Pullman

How admirable to fecl clear! To perceive without distraction or vaguethe daity for more than a few seconds. lots of things.... And to sustain this
Usually such moments are doomed by a wicked bolt of lightning that came out of nowhere destruction

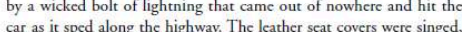

car as it sped along the highway. The leather seat covers were singed,
the radio wiring melted and the horn knocked out, but the driver,
I chose such rather extreme cases to show the poet's playfulness when breaking his lines. Line breaks in Padgett's poetry are put to poetic and conceptual use.

\section{Line Cuts}

The vertical poetic space that lines create does not go without saying-which is very different from pretending that all you have to do is "Hit enter / A lot"8. You may have to hit enter a lot, but you have to acknowledge that this is a transformative action (of linguistic substance and meaning). Ron Padgett warns us several times about the power of line breaks and the consequences of cutting.

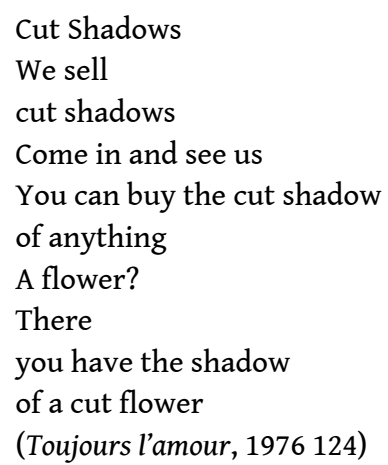

"Cut Shadows" can be read meta-poetically: "We"-the poets?-“sell cut shadows": the expression is repeated three times as if "cut shadows" were a well-known best-selling product. However, at the first purchase occasion, we do not obtain "the cut shadow / of a flower," we are given "the shadow / of a cut flower." The implication is that cuts are 
not clean, they do not stop at their point and time (the line break), they travel, slide, and run. If we buy the cut shadow of a flower and, instead, receive the shadow of a cut flower, it means that the formal operation of cutting (cutting a shadow) has been translated into material reality. Likewise, operating a cut somewhere in a sentence leaves traces on meaning, on both sides of the break. The decision of cutting the line is consequential by definition (logically and conceptually). As a result, sentences that are versified become an active milieu, a field of tension where linguistic relations and movements are registered.

The poem conjures up Mallarmé's ideal flower, "the one absent from any bouquet" (76). In Padgett's poem, the flower is cut because it's a paper flower, the flower of poetry. Line breaks mark and conceptualize separation and absence, as if before the first line (or title) of each poem there were a concealed, insurmountable line break no enjambment could ever straddle: the line break that would theoretically lead us back to the poet, to the moment of living and writing.

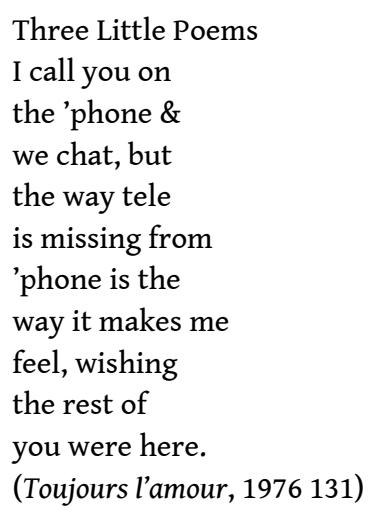

In the first of "Three Little Poems," "tele" is missing, separated from "'phone," two line breaks away, staging the speakers' distance, the archaic use of the apostrophe expressing the nostalgia for a time when "phone" was still known as an abbreviation". However, when the poet says that he wishes "the rest of / you were here," in spite of his melancholy, he nevertheless means that part of you is coming through the phone and the poem, both allowing a form of presence. Unlike Frank O'Hara who, in "Personism," realized "while [he] was writing [...] that if [he] wanted to [he] could use the telephone instead of writing the poem" (499), Padgett's speaker here is not choosing between the phone and the poem, he is using both. A paradoxical activity, the writing of the poem inscribes separation and distance at the end of each line; and yet, it continues its downward movement, as if to make up immediately for the cut it just created in the sentence, in the hope that the flow of syntax reactivated by reading will recreate a sense of continuous presence. "[...] wishing / the rest of / you were here": if read individually, the three lines are mere rests (remains and pauses), fragments cut off from a greater ensemble. Reading the sentence over the line breaks gives back their unity and coherence to things and beings, even in the face of absence (the loved one is only partially here). Line breaks simultaneously create distances and issue invitations to bridge them. In "Radio," the commercial description of the radio spreading over four short lines symbolizes the possibility of remote and distant communication, which is also the hope of the poem: making present that which is absent.

Another all-wave radio, as if to emphasize

the ease

with which 
far-distant stations can be heard,

is equipped with remote control.

(Toujours l'amour, 1976 159)

Line breaks are meant to be overcome, run over, and read beyond: the process of reading down the lines activates a form of presence in the face of absence and separation. Reading reconnects what line breaks disconnect: the "all-wave radio" has to wait four lines to be granted its verb "is equipped."

\section{Line Stops}

Absence is not only the absence of far-away friends, lovers, unknown speakers, but also the paradoxical absence of the poet to himself. It is as if line breaks were the mark of the poet interrupting himself in the middle of it all in order to write a poem. The activity of writing is an interruption of experience, a reflective life break replicated in the text itself by the line breaks.

Stop and Go
I would like
to pause here
in the day's
occupation
to say
that I think
Harrap's
Standard French
and English
Dictionary
is a wonderful
book,
Echappez-vous!
Run away!
Edited by J.E.
Mansion M.A.
(Tulsa Kid, 1979 217)

In "Stop and Go," the poem is a pause in the poet's day, as each line is a pause, an interruption, itself interrupted by fast returning line breaks. The tall narrow layout of the poem, which makes for its rapidity, also produces a sense of claustrophobia: the poet stops going about his day to write a poem that invites us to go and explore a big, thick book, the dictionary. This is counterbalanced by the two words he chooses "Echappez-vous! / Run away!" However, it is not certain that the escape will be provided by a return to life since the route to freedom seems to be mediated by the language found in the dictionary. To escape is first and foremost to read, to connect back together the lines that were separated.

Poem

I'm in the house.

It's nice out: warm

sun on cold snow.

First day of spring

or last of winter.

My legs run down 
the stairs and out

the door, my top

half here typing

(Tulsa Kid, 1979 237)

In "Poem [I'm in the house]," at the same time as he is busy typing his poem, his body separates in two and his legs scamper away to enjoy the warm sunny day, his upper body staying at his desk. The activity of typing here is not followed by any enjambment, the poem stops short, with the poet's upper half stuck inside; outside access is only offered the legs precisely because they run down three lines ("down / the stairs and out / the door"). Legs are literally (and metaphorically) made for enjambment. Line breaks therefore are meant to be run-on and enjambed: if we stop in one line, we will not go anywhere, whereas the transitive flow of line-straddling syntax will take us places. "Stopping and going" is therefore one way to describe writing and reading poems, stopping on each line as long as we keep going: there lies the basic tension between line breaks understood as the end of lines and enjambment understood as the syntactical movement that goes beyond.

\section{Drop Me a Line}

\section{A Bit of a Stretch}

Where are we going when we read a poem by Ron Padgett? What is there beyond the end of the line? What are we to expect? If line breaks force momentary stops-albeit extremely brief-should we always prepare for "the strange part" "“A Man Saw a Ball of Gold" 51) ${ }^{10}$ ? The tensions between lines, line ends and run-on lines in Ron Padgett's poetry are to be understood in a context of constant instability created by his poetics of drift. In "American Cowslip," we discover that verse is the space of the unexpected, where nothing turns out to be what we expected:

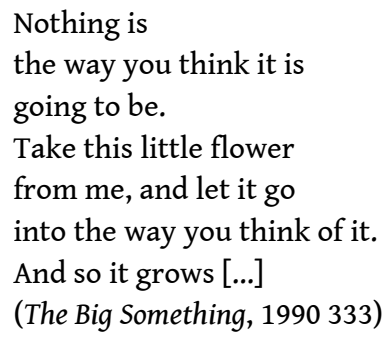

The poem becomes the locus of metamorphosis as the flower becomes Daisy the cow, who turns into the poet's grandmother. Such change is prepared by the first 6 lines: each new line gives a new direction to the preceding one, semantically self-sufficient, and, thus changes the meaning understood at first:

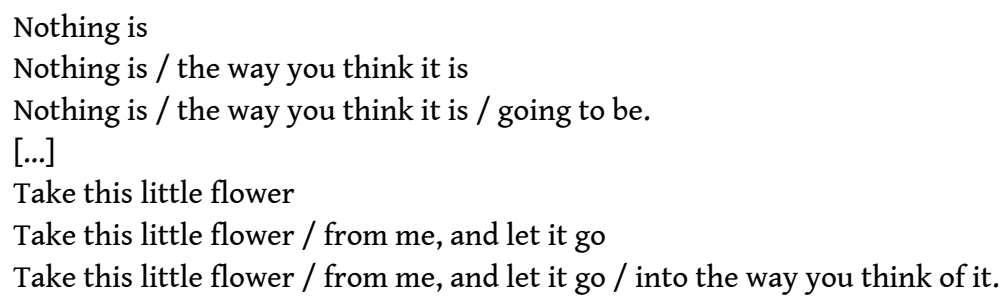
things at once: the meaning of the individual line (or group of lines) and the meaning of 
the enjambment, the meaning of the new line aggregate. "And so it grows": this is not only about the flower, but also about the poem growing, each new line adding to-and modifying-the preceding one. This bears consequences on the temporality of the poem: there is such a thing as a first time reading poems: at a second reading, we will know what to expect.

The poem is therefore an unstable place where a word might have one meaning if the reading process stops, and a completely different meaning if the reading goes onto the next lines. This is what we learn in "Ladies and Gentlemen in Outer Space," as the philosophy of the poet seems to be that everything can turn into its opposite.

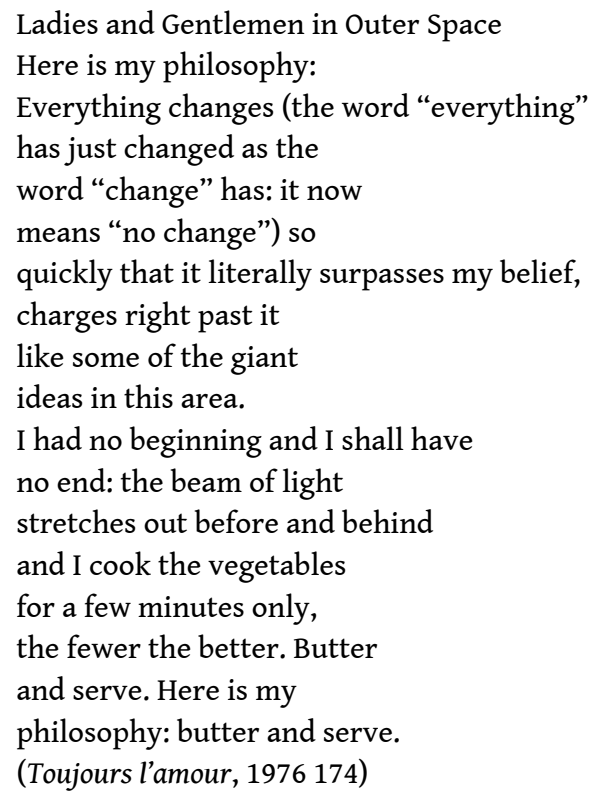

"Change," itself becoming "no change," is contingent on the possibility of the enjambment, of a syntactic and semantic life after the end of the line. Otherwise, in the second line, "everything" and "'everything" - placed between inverted commas-seem to be the exact same words: the word "everything" only changes insofar as we go from the second to the third line and read it as the subject of the verb "has just changed." Likewise, such swift change is so surprising for the poet that it "surpasses [his] belief" and "charges right past it": surpassing-understood as going beyond, overstepping, going past-hints at the possibility of running on the lines, not stopping, going beyond their ends. Astride two lines, the expression to "have / no end" is the momentary dream of the poem where "change" becomes "charge," the lines a field of energy bound forward, "stretch[ing] out before and behind." The culinary turn of the final part can be understood as a desire to go back to basics, away from the metaphysical and metalinguistic ponderings of the beginning. The danger, indeed, of such meditations is that they interrupt the transitive chain of syntax, just as the bracketed section separates the beginning of the clause "Everything changes" from its conclusion "so / quickly that it literally surpasses my belief." One may even wonder if such metapoetical parentheses do not act as line breaks within the lines. Looking at each word makes one run the risk of getting mired in language, in the line itself, not moving forward or getting anywhere. By changing the subject and talking about cooking and food, Padgett apparently stops using language to talk about language. This prosaic, transitive turn of the poem is exemplified in the last three lines: "Butter / and serve. Here is my / philosophy: butter and serve." "Butter" can be considered as a slight 
metamorphosis of the preceding word "better," as if the poem was still charging forward. Above all, it is the lubricant that will connect the vegetables together, just as the activity of serving itself is transitive, bringing food to the table, passing it to someone. What is most important in the last few lines is the play of line breaks: once separated, "butter" and "serve" are reunited in the final line, whereas the once intact grandiose first line "Here is my philosophy" is now broken. Theory is all very nice but it runs the intransitive risk of becoming self-absorbed, discontinuous, of cutting itself from its very object, the world; from practice, however, ideas can come. In the end, "butter" and "serve" are not the subject, the displacement of the line breaks is: what matters is that butter and serve are reunited, contiguous and continuous. Padgett's philosophy is to reconnect and continue in the face of apparent discontinuity: butter and verse.

\section{Down the Line}

In Ron Padgett's world of constant change, I would like to question the poems' line movements. In its deft use of line breaks and letter dissemination, "The Periscope" symbolizes the conception of the poem as descent, a good example of Ron Padgett's poetics of drift, with its play of floating prepositions, conjunctions and pronouns (personal and relative). ${ }^{11}$

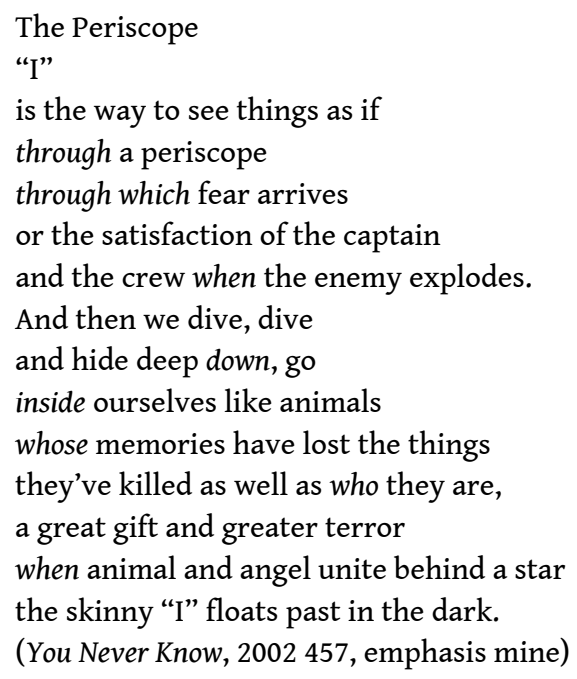

Each line animates the downward movement until the final line where the once isolated " $\mathrm{I}$ " is now seen "float[ing] past in the dark," an unfolding translation of the central metaphor of the "periscope" with the personal pronoun embedded in its midst. In "The Periscope," the reader can choose to ponder upon the metaphors if they decide not to run on the lines with the downward flow of the poem. The risk is that the reader might not find themselves floating along with the "I" in the final line: for one, because they will never get to the last line; and also because the paradoxical metaphors of the poem resist quick scrutiny, the lines moving too fast for their thorough examination. Indeed, the periscope is the metaphor of the self, or rather "I," but then "I" becomes "we" and we dive into our own selves, as if the submarine was diving into the submarine, or rather as if the periscope was going down instead of going up; can there be such a thing as a periscope inside a periscope? These clumsy quasi-metaphysical questions show the perils of sinking if one does not accept to drift down from one line to the next, if one does not go with the flow of the poem, laterally and down. 


\section{The Bottom Line}

As was mentioned in the introduction, versatility is defined by lateral, upward, and downward movements. The poem "The Sweeper" is under their sway: its central concept is the pile of dust, the pile being a metaphor for the poem itself, a pile of lines.

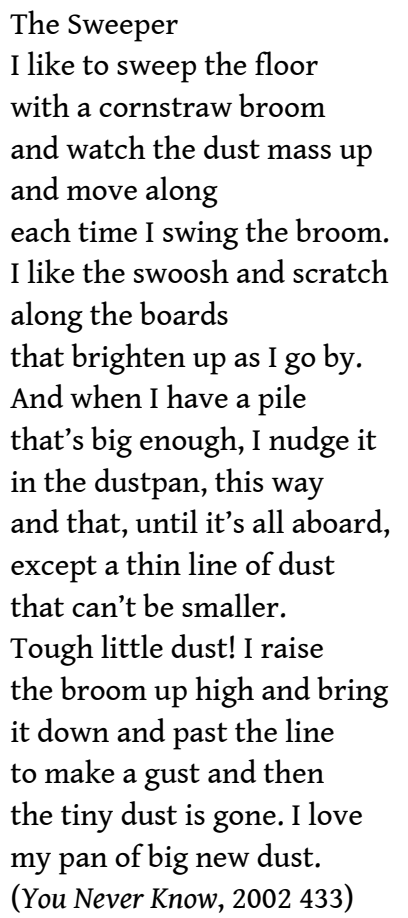

The movement is paradoxical: as the reader goes down the poem, from line to line, the pile of dust goes up. Although technically a descent, the poem is thus rather an ascent. The movement of the broom is lateral ("move along"; "I like the swoosh and scratch / along the boards") as the dust goes up in the pan. Reading each line of the poem can be compared to moving the broom from left to right; looking at the lines instead of reading them is admiring the result of the process, the pile of dust. One line being one lateral movement, the run-on line is the movement that one makes to bring the broom back into original position. This poem is about the very irritating dust leftovers that brooms are too coarse to sweep into the dustpan. It is also, I would argue, a conceptual text which makes use of the possibilities afforded by the vertical layout of lines and the process of enjambment. The only possibility to displace the last of the dust is not to engage in physical contact with it but to blow it into the pan.

\footnotetext{
Tough little dust! I raise

the broom up high and bring

it down and past the line

to make a gust and then

the tiny dust is gone. I love

my big pan of big new dust.

(emphasis mine)
}

Thanks to the line break, the words "gust" and "dust" are juxtaposed in a performative way: the broom swings right above the line of dust which disappears (dust gone) into the dustpan (dust is the last word of the poem, all things therefore seem to be in order). If the poem is a broom, and each line a movement of the broom ("each time I swing the 
broom") which materializes with its words the dust it captures, does it not also mean that the broom itself creates the dust it pretends to be sweeping away? And what do enjambments mean here? To be "enjambed" means for each line to be swept into the dustpan and join all the other lines already there. The consequence is that there will always be one last line which will not be swept by the next one, deprived as it is of a new enjambment-which provides new domestic and humorous insight into Agamben's theory of the end of the poem. The hypothesis of the "catastrophe and loss of identity" (112) at the end of the poem is here confirmed by the fact that there will always be a thin line of dust remaining on the floor. Being versatile is "moving forward or backward": we here have a paradoxical space in the sense that the first lines (of words ( dust) are the first to be swept away into the dustpan; the following ones, below them in the poem, will find themselves on top. The catastrophe, indeed, is near, as our pile of dust is upside down: what comes down has gone up.

\title{
Matters of Line and Death
}

\section{At the End of the Line}

\author{
Poet as Immortal Bird \\ A second ago my heart thump went \\ and I thought, "This would be a bad time \\ to have a heart attack and die, in the \\ middle of a poem," then took comfort \\ in the idea that no one I have ever heard \\ of has ever died in the middle of writing \\ a poem, just as birds never die in midflight. \\ I think. \\ (You Never Know, 2002 450)
}

In "Poet as Immortal Bird," Ron Padgett considers the possibility of dying in the middle of writing a poem. Not stopping at the end the line, running on the lines becomes a question of life and death, continuing writing the poem the only evidence you are still alive. But where, exactly, is the middle of the poem? It could be the interstitial space of the enjambment between two lines, and, more minimally, the space between two words. The final brief line of the poem casts doubt as to the reassurance that Padgett finds in the bird example, just as it stops the poem short. The poet's comforting argument does not make sense: there is no such thing as midflight if the bird's flight comes to be interrupted; the flight ends, that's all. Just as there is no such thing as the middle of writing, from an outside point of view-the writer's intention set aside-if the writing stops abruptly (as it does at the end of the poem). ${ }^{12}$ Incidentally, we have no evidence that the poet did not collapse on his typewriter right after writing "I think." And "Poet as Immortal Bird" could very well be only half the poem it was meant to be. So that the only spaces of life are in the movements from word to word, line to line, be it for the writer or the reader. After the last period, everybody leaves. The end of the poem is not only the death of the poem but it also rehearses the death of the poet and of the reader.

Line breaks, understood as interstices, are nonverbal turning points which presuppose writing before and after them, to their left and to their right (or down below). At once a moment of, and a passage in, the poem, a line break questions writing as printed text in its relation to the activity of writing, to autobiographical experience. The line break is a 
site of suspension, where the writing stops momentarily, and of decision, where it is cut. In this indeterminate transition, something else, something beyond the page can be pointed at: things are not set in ink just yet. Although a defining feature of verse, the line break also signals towards the outside of the poem, towards life and death.

\section{Haiku}

That was fast.

I mean life.

(You Never Know, 2002 456)

In "Haiku," the poem is a matter of line and death as the poem is based on very discreet retrospective or retroactive enjambments: technically speaking there are no run-on lines and yet, the deictic That points to what has come before, just as the second line assigns a meaning to the rather abstract pronoun of the first line. There is one line missing from the poem (not to mention the fact that the lines do not follow the haiku syllable count): this line is not to be looked for in the vacant third position, it is to be understood as a preliminary ghost line coming before "That was fast." A line whose absence, pointed at by the first word, signifies another temporality, forward driven, the temporality of life, not bound by line breaks.

\section{Coloring Outside the Lines}

In "Joe Brainard's Painting Bingo," Ron Padgett turns his poem into a line-break generator to test the validity of poetic statement in relation to life. He takes his first line "I suffer when I sit next to Joe Brainard's painting Bingo" and proceeds to cut it in different parts, to see what happens. The point he wants to make is simple: line breaking will change the meaning of the versified statement. Line breaks are not only defining features of verse, they are generative elements in the variable geometry of the poem. Here, the line-break variations become pretexts for the writing of entire stanzas spurred on by the new meanings created by line breaking. An exercise in composition and disposition (the reference to Brainard's painting might be an extra incentive to play with lines), the poem insists on the meaningful consequences of the contingent nature of line breaks.

Joe Brainard's Painting Bingo

I suffer when I sit next to Joe Brainard's painting Bingo

I could have made that line into a whole stanza

I suffer

When I sit

Next to Joe

Brainard's painting

Bingo

Or I could change the line arrangement

I suffer when I sit

That sounds like hemorrhoids

I don't know anything about hemorrhoids

Such as if it hurts to sit when you have them

If so I must not have them

Because it doesn't hurt me to sit

I probably sit about 8/15 of my life

Also I don't suffer

When I sit next to Joe Brainard 


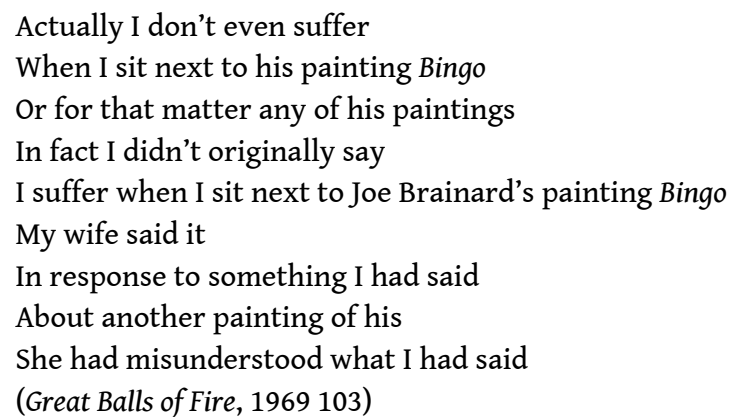

There are four moments in the poem:

1) the first line the reader is invited to take at face value; 2) the first line processed through the poet's line-breaking machine, creating new configurations of meaning; 3 ) the poet's methodical doubt applied to the new generated lines and his refutations: from "it doesn't hurt me to sit" to "I don't suffer / When I sit next to Joe Brainard" to "Actually I don't even suffer / When I sit next to his painting Bingo." Breaking the lines allows Ron Padgett to test the end-stopped fragments and see if they hold as statements. The process of line breaking can therefore be understood as a test of authenticity; 4) the conclusion of the poem which is that he did not originally say this line.

In this poem which he called "a little study in line breaking,"13 Padgett shows us that the process of breaking a line will transform everything and turn language into what it is not: it will make you say something that you did not say. In line breaking lies the possibility of misunderstanding. This may also be related to the title of Joe Brainard's work Bingo: a reference to the lottery game, hence to chance arrangements; but also to lines as structural elements of a grid, and of the poem. "Bingo" is also what one shouts when receiving a winning combination of numbers in a straight line. As structural elements of the poem, line breaks thus allow us to both miss the point and get it, to say one thing and its opposite: they are dual, ambiguous agents. Padgett writes that he "probably sit[s] 8/15 of [his] life": The fraction bar, I would argue, is just another line break, or life break: line breaks allow us to measure, calculate, and divide. Because it produces lines, the process of breaking is foundational as it allows us to sit and rest, without immediately having to go forward.

In the final stanza, the first line is repeated, only preceded by "In fact I didn't originally say," which sends us back to the beginning of the poem. Just as the final line of a poem is missing an enjambment that would prolong the poem onto a subsequent line, we could also say that the first line is also always missing a preceding enjambment which could alter its meaning. This is an invitation to paranoia: Padgett's poem invites us to wonder if we're not always missing a line which could have come before the first one. Here, that line is provided by the poem: "my wife said it." I would like to read the line "In fact I did not originally say" on its own, and thus question originality in poetry understood as authenticity as well as priority. There is no such thing as a first line that would come out of the blue: there is always a preceding ghost line from which the poem is broken and breaks, as well as a preceding ghost enjambment that we cannot see.

At the end of the day, it does not quite matter if Padgett's wife misunderstood what he said, if it was about another painting anyway, because he wrote a poem entitled "Joe Brainard's Painting Bingo" which we misunderstood at first: this was the whole point. 
We could consider that the title is yet another fragment cut off from the first line, as if it were another line that had broken away from the poem. But also that the title is missing a preceding line, "I suffer when I sit next to," as if the poem could start writing itself in reverse from the title upward.

\section{You are Next in Line}

In his long poem "Method," Ron Padgett insists on the unruly, overflowing quality of his lines. Remembering his friend and mentor Kenneth Koch's instruction, Padgett soon realizes that he is not capable of sticking to end-stopped lines, but that all his wishes come "pouring forth," going from one line to the next, their flow straddling several lines at once.

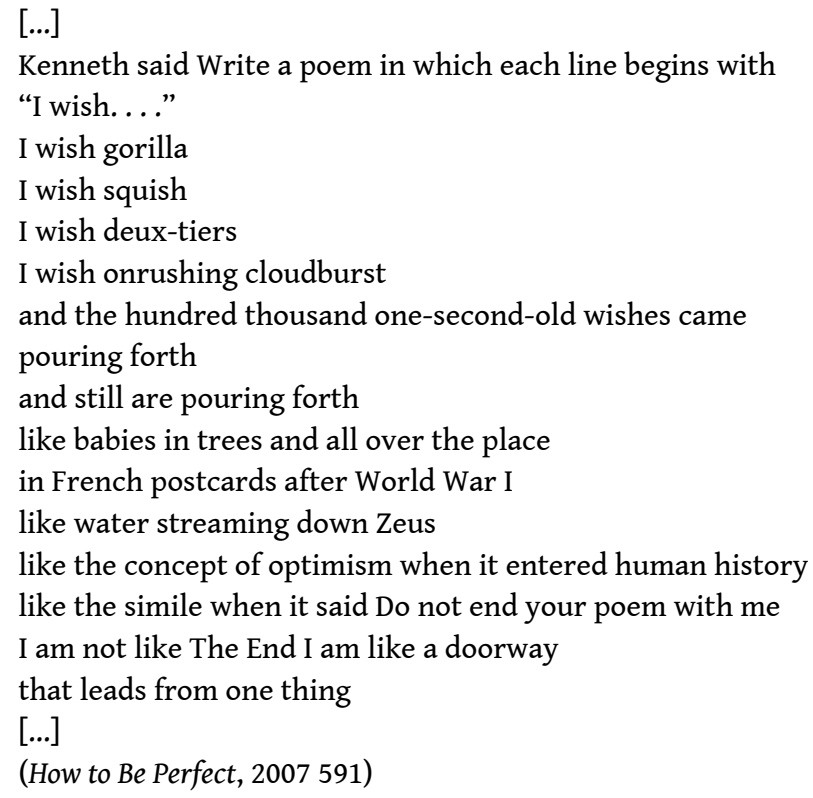

51 The line in Ron Padgett's writing is an essential element of his method which "is to start and go / wherever the poem seems to lead." In another passage from the same poem, Padgett talks about "the similes [which] can line up / to form the log cabin Lincoln / is said to have built with his own similes." "Lining up / to form": the postposition "up" insists on the importance of verticality, Padgett's sentences often winding over several lines. "Lining up / to form" means that the poem is built like a cabin, by piling up lines or logs.

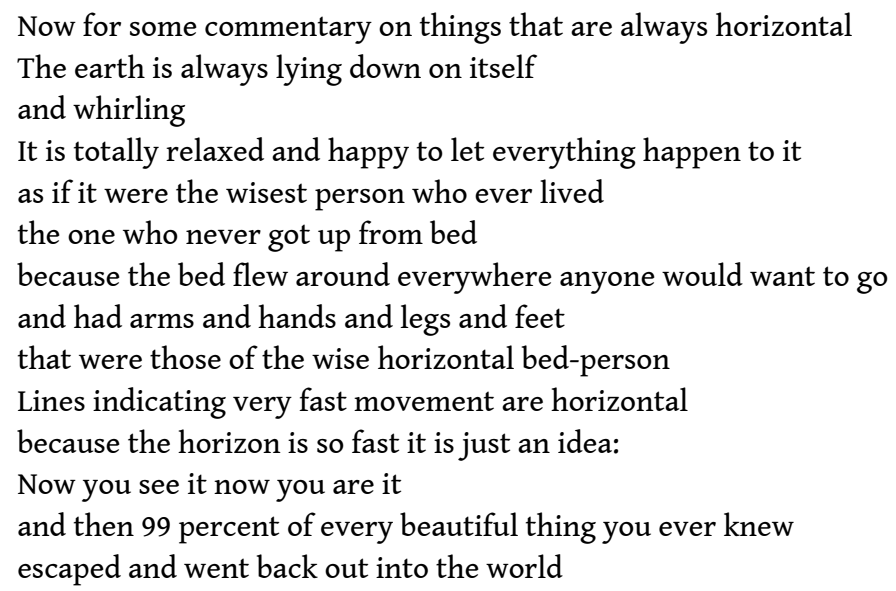


where you vaguely remembered it: your mother's smile in the glint of sunlight on the chrome of a passing car, her tears in a gust of wind, her apron in the evening air as if she were a milkmaid standing in Holland while those silver and gray clouds billowing across the sky over to scarlet and burning violet tinged with gold

were just for her and that one moment. (592-3)

"Things that are always horizontal," an apt definition of lines, end up making and building things and "the wise horizontal bed-person" could be a metaphor of the poet himself, travelling all over the world on the bed of his lines. In his poetic musings about the horizon, Padgett is also reflecting on the nature and structure of poetic lines: when he writes that " 99 percent of every beautiful thing you ever knew / escaped and went back out into the world," he is playing with two line breaks: the one hiding in the percentage, allowing for the possibility that $1 \%$ stays where it is; and the line break separating the subject from its verb "escaped." Run-on lines are possibilities of escape, of moving on, of memory, depth, and fiction, as the subsequent lines show, where the poet remembers his mother's smile distantly reflected in "the chrome of a passing car," before imagining her as a "milkmaid in Holland."

And sooner or later, the poem leads to you:

You are next in line, which is exciting,

which is why life is exciting: every moment is another line

you're next in. Or maybe not, for what about when

you don't know what "line" is and "next"? (593)

The set expression "you are next in line," which the poet is going to literalize, means that "it's (going to be) your turn." One feels like asking what this is all about: your turn to do what? to go where? to go "back out into the world"? Read by itself, the line seems to indicate that the very idea of being next (the forward movement of life) is exciting in itself. But when Padgett rearranges the line and breaks it, the process of line-breaking can also be understood as defeating the relentless forward movement of life-however celebrated it might be. The new expression "another line / you are next in" plays with chronology, as if writing was going against the flow, showing that writing can take its liberty with temporality and sequence because "another line" now comes before "you're in." By inverting the syntactical order, adding the adjective "another" in front of "line," by spreading the expression over two lines, thus making it slower, Padgett reintroduces temporality in the figure of speech "next in line": no longer a set expression, it's now open to scrutiny, as if elongated, quartered over two lines. The enjambment is retroactive in the sense that the relative clause "you're next in" comes logically before "another line" on the preceding line. Yet, we can also consider that the line break and enjambment allow the poem to do what it says: with the disappearance of the word "line" left behind, "you're next in" becomes performative: the four words can be read as standing their own ground, being by themselves in their own line which no longer needs to be named. The confusion as to what "line" and "next" mean is perfectly understandable, since one can read this passage either as writing resisting temporality or enacting it. "But it doesn't matter because you started out a man / and ended up a pile of leaves in a different story." The poem is a "different story" from life. And I would read this distinction as being parallel to the difference between "being next in line" and "another line / you are next in." In life, the man you start out to be is next in line; he ends up as a pile of leaves in the poem because the poem is a pile of 
lines he is next in. When life seems to be unidimensional, a single line, the poem or the book is a pile of leaves. Poetry breaks the line of life/biography to make piles out of it.

\section{Conclusion}

In his long essay, Frank Kjørup writes that "line-break cannot be valid as a doubly descriptive term, as it were, that is, referring to an event both linear and syntactic, since the breaking of the line does not by necessity entail a breaking of syntax in the sense of enjambement." (32) Lines can be end-stopped, followed by a structural line break (the breaking of the structural line, not of its syntax). To conclude this attempt at reading Padgett's line breaks, I would therefore like to question line breaks in poems where they seem least obvious. Ron Padgett's sonnet "Nothing in that drawer" consists of 14 identical end-stopped lines without any form of enjambment.

Nothing in That Drawer

Nothing in that drawer.

Nothing in that drawer.

Nothing in that drawer.

Nothing in that drawer.

Nothing in that drawer.

Nothing in that drawer.

Nothing in that drawer.

Nothing in that drawer.

Nothing in that drawer.

Nothing in that drawer.

Nothing in that drawer.

Nothing in that drawer.

Nothing in that drawer.

Nothing in that drawer.

(Great Balls of Fire, 1969 23)

At a first reading, there does not seem to be much to say about the spaces between each line: words (and therefore rhymes) are identical. However, because the only repeated line of the poem stages someone going through each drawer of what must be a fairly large piece of furniture, the superimposition of identical lines has the following consequences-based on the assumption that the writing happens at the moment of the search: since the speaker finds nothing in the drawers, the poem-checklist repeats the same emptiness in the exact same words on each line. Nothing was found, there is nothing to report, nothing changes. What changes, however, is the growing "imagined" emotion of the speaker who cannot find what he is looking for. Nothing is happening in the poem as a result of the speaker's investigation. Each line comes home emptyhanded, nothing is happening in the lines which are the vain reports of the speaker's failed ransacking. However, the poem is happening in the spaces between each line, the spaces of life and experience where the speaker opens another drawer with eagernessonly to find nothing yet again. Such spaces of anticipation, curiosity, and eagerness provide silent counterpoint to words.

I would like to read Padgett's poem as a conceptual poem, which, I would argue, would not be out of place in Craig Dworkin's and Kenneth Goldsmith's anthology Against Expression: An Anthology of Conceptual Writing: executing a central idea, "Nothing in that Drawer" ironically displays its unoriginality by plagiarizing its first line thirteen times. ${ }^{14}$ Life beyond the poem is happening; the search is taking place between two lines: this 
is where all the feelings of excitement and eagerness lie. It could be objected that nothing proves Ron Padgett wrote the poem at the very moment he was going through his drawers, and that it is even unlikely. This objection is certainly valid but it does not change much to the poem: the first line says that there is nothing in the drawer, which is what all lines repeat. By turning this sonnet into one of the most uneventful sonnets of the history of poetry, Padgett turns over the spaces between the lines to the reader who will either fill them up with anticipation and curiosity at a first reading; or boredom, at a second reading; or pleasure at seeing how smart this conceptual piece of writing is; or dread, at the prospect of having to read it aloud. So whether the writing of the poem is coincidental with the failed investigation, whether the latter happened or not, the text would be the inert, disappointed report of a search if it were not a poem, and if the spaces between its lines did not formalize and offer spaces of poetic possibility. To read this poem, one does not only have to read the words and the lines, one has to read the line breaks understood as the spaces between each line which point to the biography of the poem (whether the writer's or the reader's at the moment of reading). Beyond horizontality and verticality, this sonnet adds another dimension to poetry: line breaks as interlinear spaces-the moments when the speaker opens and closes the drawers-turn the poem into a three-dimensional space. This is why I would like to argue that line breaks are not only spaces but they also represent the possibility of volume in literature. One radical example is Raymond Queneau's Cent mille milliards de poèmes where each line of each one of his ten sonnets may permutate with other lines from the other sonnets. In that case, the line break and rime systems operate not only on the page but also between the pages, to produce countless more sonnets than the slim volume apparently holds. In Padgett's sonnet, the irony is that the lines qua drawers are empty. And yet, at the same time as they point to their referential vacuity (there is nothing in the drawers), as they seem to fall back upon themselves in the act of repetition, they nevertheless bank on their power of suggestion and on the reader's eagerness to fill the drawer from one line to the next. The lines of Padgett's sonnet are referential after all (they make us imagine empty drawers): emptiness here is an image which begs for more images and urges us to imagine things in the drawers, to see more things than meets the eye and the line.

In "Bob Creeley Breakthrough," as the poet imagines a young woman about to "remove [...] / her blouse," his heart starts "pounding so hard" that his lines become increasingly shorter to the point of evoking the poetry of Robert Creeley, who crashes the poem.

Bob Creeley Breakthrough

This is going well today

I mean the fingers typing

and the face smiling

and the breath going in and out

like a nice girl on a date

who for the first time removes

her blouse, but your heart

is pounding so hard you

can't actually

see anything

except a mental

image

of Robert

Creeley 


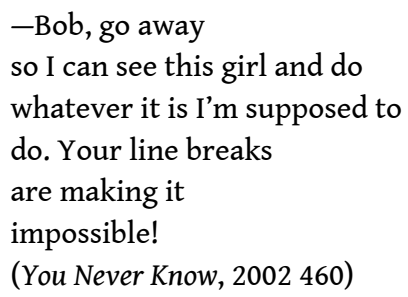

In the final stanza, Padgett implores his friend to go away as Creeley's "line breaks / are making it / impossible!" The indeterminate nature of the pronoun "it" here leaves little doubt as to its nature in the context of sexual fantasy of the poem. Instead of evoking some kind of erotic activity, the line breaks of the second stanza draw attention to themselves (one may even wonder whether the poet Pound is not hidden in the pounding of the heart) and turn the poem into a meta-poetic one: so much for eroticism. The line breaks here are turning into breakthroughs, the poet is incapable of looking at what words mean but he is only seeing the words themselves, their arrangements, their literary nature and history. Instead of offering words that would point to a conventional erotic scene in a transitive use of language, the poem's surface becomes intransitive and turns into a meta-poetic nightmare as an image of Robert Creeley (the nature of which is not determined) blocks access to the object of desire. Yet, the thought of the nice girl and Robert Creeley's uncalled entrance are not as unrelated as they may seem; I would even argue that what the speaker's erotic thoughts and the intrusion of Creeley's line breaks have in common is the author's interest in shapeliness. During the Paris symposium on his work, Ron Padgett defined the role of line breaks in relation to energy and form:

You know, in a way, line breaks are a form of punctuation. They are a way of shaping, not only the meaning of the poem, [...] but they're also... they determine the kinetics, let's call it, of the poem. I said "flow" earlier, whatever you want to call it. And to me, the flow of a poem down the page... and the poems I write usually go down the page, they don't have to, but they might do ... and that flow from start to finish to me is very important. More important than the words, I mean, the actual content or the feeling or anything else. It's to get a poem that has to keep going. It should keep going. And you've read a lot of poems, I'm sure, where you go about halfway through and you kind of wonder: should I keep reading the poem? It's not that it's a bad poem, it's just there's no forward momentum. There's no kinetic movement forward. And I've written poems like that too, believe me, but I'm very concerned with it. And line breaks are a way of making the poem shapely in its own terms. There's no theory. There's no template that says you must do every line break this way. No, I mean, look at Creeley! Creeley is a very good example of a master of line breaks, a master! And that was one of the first things I noticed about him when I first read him was the way he broke the lines, it was really amazing. So, I mean, in brief, that's why I think [...] they could be so important in shape, creating the shape of the poem. And I like shapely poems a lot. ${ }^{15}$

In "Bob Creeley Breakthrough" the object of desire is not so much the shapely body of the "nice girl on a date" as the dream of, and hope for, a shapely poem. The shape of the poem, its kinetics and energy request that the erotic line break in stanza two ("like a nice girl on a date / who for the first time removes / her blouse") be followed and superseded by other line breaks. The deferred promise of erotic pleasure is here replaced by aesthetic and poetic pleasure. And if Creeley's line breaks are blurring Padgett's line of vision, if, as characters in the poem, they are misbehaving, at least they have informed Ron Padgett's own line breaks and have kept the poem going beyond the initial erotic moment which it might have been delicate to dwell or 
conclude on. Line breaks do not only punctuate the poem, but they are also instrumental in the self-reflexive and self-fashioning momentum of the poem. They make as much as they break, they show the way.

\section{BIBLIOGRAPHY}

@BillMurray Twitter Account. “A Sentence...” 1 May 2013. Accessed 7 December 2018.

ADAMS, Michael, Laurel J. Brinton, and R.D. Fulk. "pick up + telephone/phone," Studies in the History of the English Language VI: Evidence and Method in Histories of English, Berlin: Walter de Gruyter, 2015. Online. Accessed 17 October 2020.

AGAMBEN, Giorgio. The End of the Poem: Studies in Poetics. Translated from the Italian by Daniel Heller Roazen. Stanford: Stanford University Press, 1999.

ALLEN, Donald. The New American Poetry. New York: Grove Press, 1960.

BROSSARD, Olivier. "Le parti pris de quelque chose." Le Grand Quelque Chose by Ron Padgett. Translated from the English by Olivier Brossard. Nantes : Joca Seria ("coll. américaine"), 2010.

CERTEAU, Michel de. The Practice of Everyday Life. Translated from the French by Steven Rendall. Berkeley: University of California Press, 1984.

DWORKIN, Craig. "The Fate of Echo." Against Expression: An Anthology of Conceptual Writing. Eds. Craig Dworkin and Kenneth Goldsmith. Evanston: Northwestern University Press, 2011, p. xxiiiliv.

HALTER, Peter. "The Poem on the Page, or the Visual Poetics of William Carlos Williams." William Carlos Williams Review, vol. 32, no. 1-2, 2015, p. 95-115.

HOLSAPPLE, Bruce. “The Verse Line in Williams.” English Studies in Canada, vol. 33, no. 4, December 2007, p. 127-148.

KJøRUP, Frank. "Exploring the Conceptual Implications of Poetic Line-Break: from Terminology to Phenomenology." Acta Linguistical Hafniensia: International Journal of Linguistics, vol. 42, no. S1, 2010, p. 20-50. Accessed 7 December 2018.

LEVERTOV, Denise. “On the Function of the Line." Chicago Review, vol. 30, no. 3, winter 1979, p. 30-36.

MALLARMÉ, Stéphane. Preface to René Ghil's Traité du Verbe (1886), Crise de vers / Crisis in Poetry. Translated from the French by Mary Ann Caws. Selected Poetry and Prose. Ed. Mary Ann Caws. New York: New Directions, 1982.

McHUGH, Heather. "Love and Frangibility: An Appreciation of Robert Creeley." American Poetry Review, vol. 26, no. 3, May-June 1997, p. 9-16.

NOTLEY, Alice. "Ron Padgett's Visual Imagination." Coming After. Essays on Poetry. Ann Arbor: The University of Michigan Press, 2005, p. 27-41.

O'HARA, Frank. The Collected Poems of Frank O'Hara. Ed. Donald Allen. Berkeley: The University of California Press, 1995. 
PADGETT, Ron. Collected Poems. Minneapolis: Coffee House Press, 2013.

PADGETT, Ron. Poets and Critics Symposium. Université de Paris / Institut Universitaire de France. 10-11 July 2017. www.poetscritics.org

SHAMMA, Yasmine. Ron Padgett's Inner-Outer Spaces Spatial Poetics. Second Generation New York School Poetry. Oxford: Oxford University Press, 2018, p. 150-183.

THOMAS, Lorenzo. “The Pleasures of Elusiveness: What Is In and Around Ron Padgett's Poetry." Don't Ever Get Famous. Essays on New York Writing after the New York School. Chicago: Dalkey Archive Press, 2006, p. 288-302.

\section{NOTES}

1. Yasmine Shamma does mention the "transitional properties of a line-break" in her reading of "Gentlemen Prefer Carrots," inviting the poem's speaker to have a broader view of the scene in front of him. (161)

2. Michel de Certeau develops the concept of non-lieu in the chapter on "Names and Symbols" in The Practice of Everyday Life: he shows that proper names in modern urban spaces, "spaces brutally lit by an alien reason, [...] carve out pockets of hidden and familiar meanings. They 'make sense'; in other words, they are the impetus of movements, like vocations and calls that turn or divert an itinerary by giving it a meaning (or a direction) (sens) that was previously unforeseen. These names create a nowhere in places; they change them into passages." (Certeau 183)

3. In a recent message to the author, Ron Padgett wrote: "It makes me very happy to think of you pondering my line breaks. (Don't forget the stanza breaks.)” Email, 8 June 2018.

4. Ron Padgett refers to the first line of the poem "Poet as Immortal Bird," ("A second ago my heart thump went"), Collected Poems, 450.

5. "I intend to approach Padgett's poetry as a visionary poetry" (Notley 28).

6. "I had already read a lot of so-called Imagist poetry in the English language, and I had already been very influenced by William Carlos Williams." Poets and Critics Symposium, 10 July 2017, Université de Paris / Institut Universitaire de France, poetscritics.org.

7. See "This for That," Collected Poems 552.

8. @BillMurray Twitter account quoted in the call for papers "Line Breaks in American Poetry," Universités Paris 3 - Paris 8, 16 June 2018.

9. The shortened phone has become increasingly used as a word per se in the $20^{\text {th }}$ century, "surpass[ing] telephone in COHA in the 1960s." (Michael Adams, et al.)

10. "A Man Saw a Ball of Gold" is, as Lorenzo Thomas writes, "an exercise in plagiarism" as it copies "Stephen Crane's [poem], almost word for word, digressing from the original only by replacing the last word in the first stanza (Crane's 'clay') with his own word 'gold."' (Thomas 297).

11. In The Big Something (1990), the second poem, "First Drift," puns on draft/drift to launch a movement of constant derivation, translation and revision from line to line. See Brossard, 2009.

12. "in the middle of writing / a poem": There is a form of ambiguity enacted by the line break here between writing as activity and writing as the resulting text.

13. Poets and Critics symposium, 11 July 2017.

14. See Dworkin xliii-xliv. In the present case it could be argued that the first line of Ron Padgett's sonnet is still "creative"; and that the sonnet is having its both self-referential and referential ways, luring the reader into imagining the drawer and its contents at the same time as it replicates the line, insisting on its vacuity. The paradox is that in order to agree on the 
emptiness of each drawer of each line, one has to compromise with referentiality, by imagining the drawer and its contents or lack thereof.

15. Ron Padgett, Poets and Critics Symposium, 11 July 2017.

\section{ABSTRACTS}

"No ideas but in hinges," poet Stephen Rodefer once quipped in his poem "Numberless Shadows," playfully modifying William Carlos Williams's famous line. This essay examines line breaks as poetic hinges in the work of Ron Padgett: they are flexible spaces where the parts of the poem turn and articulate, the lines poised between conflicting forces, between formal interruption and syntactical momentum. An attempt at defining such versatile spaces, this essay seeks to explore line breaks as the pretexts for Ron Padgett's metatextual poetics. Line breaks are pivotal points: not only are they constitutive of verse, but they also provide occasions for the poem to reflect upon itself. In Padgett's work, they are critical junctures, when language hesitates between transitive and intransitive impulses.

Le terme « line break » en anglais désigne à la fois l'acte de couper le vers et l'espace situé entre la fin du premier et le début du deuxième vers ainsi né. Cet espace est parfois désigné par le terme "enjambement» utilisé de même en anglais. Cet article interroge les difficultés de définition et les questions conceptuelles soulevées par cette notion, à la lumière du traitement que lui réserve le poète Ron Padgett dans son œuvre. Dans ses poèmes, l'enjambement est l'occasion d'un jeu au double sens de mouvement et d'« espace ménagé pour la course d'un organe" (Le Grand Robert). Les enjambements sont ces étranges espaces animés de tensions contraires (clôture et continuité) qui créent du jeu dans le poème : syntaxe et grammaire peuvent alors sortir de leurs gonds. Chez Padgett, le tournant que prend chaque fin de vers pour mener au suivant est l'occasion pour l'acte poétique de se remettre à chaque fois en jeu, suspendant son cours ne serait-ce qu'un instant avant de continuer. Cet article propose de lire les enjambements chez Padgett comme les lieux privilégiés de la réflexion métapoétique, le moment et l'endroit précis où le poète mesure ce qui fait et défait le poème.

\section{INDEX}

Keywords: Ron Padgett, American poetry, verse, line break, enjambment, run on line

Mots-clés: Ron Padgett, poésie américaine, vers, fin du vers, enjambement

\section{AUTHOR}

OLIVIER BROSSARD

Université Gustave Eiffel 